\title{
DISCUSSION OF POWER THROUGH THE EYES OF THE MARGINS: PRAXIS OF POST-COLONIAL AETA INDIGENOUS WOMEN HEALERS IN THE PHILIPPINES
}

\author{
Rose Ann Torres* \\ Sociology and Equity Studies in Education, \\ University of Toronto, 252 Bloor Street West, \\ Toronto, Ontario M5S 1V6, Canada \\ email: rose.torres@utoronto.ca \\ Dionisio Nyaga $^{* *}$ \\ Social Justice Education, \\ University of Toronto, 252 Bloor Street West, \\ Toronto, Ontario M5S 1V6, Canada \\ email: dnyaga.nyaga@mail.utoronto.ca
}

Published online: 15 July 2016

To cite this article: Torres, R. A and Nyaga, D. 2016. Discussion of power through the eyes of the margins: Praxis of post-colonial Aeta indigenous women healers in the Philippines. International Journal of Asia Pacific Studies 12 (2): 31-56, DOI: 10.21315/ijaps2016.12.2.2

To link to this article: http://dx.doi.org/10.21315/ijaps2016.12.2.2

\begin{abstract}
This article is based on a research study conducted in the Philippines. It explores the experiences of Aeta Indigenous women healers on how power becomes deconstructed through their stories and practices. This study employs the Talking Circle as a methodology to legitimate the voices and experiences of Aeta Indigenous women healers, and draws on this knowledge to remedy the systemic exclusion of Indigenous knowledge in the academy. These stories unveil the contribution of Aeta Indigenous women healers to the discourse of power.
\end{abstract}

Keywords: Indigenous, post-colonial, power, women, healing, Aeta 


\section{INTRODUCTION}

Power has been misconstrued as a concept that can only be wielded by the powerful individuals and institutions in our society. In most instances, power is theorised as a commodity that can be passed over to the marginalised group. However, Foucault (1980) says that power is neither given nor exchanged; it is not recovered but is rather exercised. The common misconception of power idealises it as being available only to certain groups of people and absent to others. This Hobbesian outlook (Foucault 1980) denies the subjugated group the ability to identify power from their own stories and ways of thinking. It makes the oppressed people reject their own ways of thinking and practices, with the thought that they have no knowledge that can bring forth power. According to Foucault, knowledge has power; it is through knowledge that power finds its efficacy. Power is also important in the distribution of knowledge, particularly in today's capitalist societies. This knowledge can be used to discipline and control the social bodies.

Post-colonial studies invite us to think beyond the production of knowledge and how that can be a powerful weapon for emancipation of the colonised bodies. Foucault tells us that the power that was held by the totalising narratives is currently facing competition from the subjugated knowledge. What we are currently seeing is the vibrancy of the subjugated knowledge within and without the academy. There is a great re-historisation and re-presentation of Indigenous ways of knowing in the academy by the formally colonised bodies. There is a growing body of literature that is debunking the misrepresentation of the Indigenous peoples of the world. Indigenous scholars have discovered the power within them and their community to find and reclaim their space within the colonised academic space. What we are witnessing is the growth of story-telling and Indigenous practices in the re-definition of what is power. Foucault calls us to see power as a fluid concept that is everywhere and accessible to all. From this we are able to learn that even the so-called powerless have their ways of exuding power. Power is passed through people in the form of a capillary, such that everyone is able to wield power.

For the purposes of this paper, power is exemplified through how the Aeta women healers serve their community through healing, environmental caring, and social gatherings. It is an example of how power becomes deconstructed through their stories and practices. Thus, to illustrate how Aeta Indigenous women healers contribute to the discussion of power: first, we discuss the Aeta Indigenous women healers' backgrounds; second, we show the methodology used for this study and how this methodology 
contributes to the discourse of power; third, we discuss power as a capillary; fourth, we explore the contribution of Aeta women healers on the nexus of knowledge; fifth, we examine the ability of the Aeta Indigenous women healers power to recognise the existence of the cosmos; sixth, we look into their contribution to discourse; and finally, we conclude.

\section{BACKGROUND}

The authors conducted research among the Aeta Indigenous women healers in Cagayan Valley in the Philippines in 2010. The Aeta people have been referred differently depending on their geographical locations. For example: Ata (in Zambales), Batak (in Palawan), Dumagat (in Sierra Madre), Mamanua (in Mindanao), Negrito (in Panay) (Shimizu 1989: 9) and Agta (in northeastern Luzon). In most of the Philippines' historical books, writers like Gagelonia and Zaide refer to Indigenous Peoples in the Philippines as "early Filipinos." Even though this has been the case, Indigenous women healers in this study identified themselves as Aeta. They are situated in Cagayan Valley; at the foothill of the Steep Mountain, on the western side of Sierra Madre. Historically, the Aeta Indigenous people were transitory, practicing swindling agriculture. They built temporary shelters that were made of banana leaves. They would use the shelters as a hunting center for a week, after which they would migrate to other places (Gravan 1964). Peterson cited by Jocano (2000), has explained why the Aeta chose to live in these locations:

The choice of where to camp is influenced by factors such as desire for food available in a given area, paucity of chosen foods in other areas, attraction of kinsmen, especially favored relatives, and escapes from growing tensions in a previous pisan (46).

The Aeta women Indigenous healers who participated in this study have a historical presence in Cagayan Valley. Their ancestors opted to occupy this place after they were militarily displaced from different lands. Participants could not specifically identify where their ancestors came from. This traditional territoriality is why the Aeta people have stayed until now and eschewed peregrination. They believe that Cagayan Valley is where their ancestral terrain is located. This is where their ancestors were buried and where they practiced their cultures and traditions. This is the place where they continue practicing their healing power, following in the footsteps of 
their ancestors. It is where the spirits of their ancestors reside. They believe that they will be punished by the spirits of their ancestors if they destabilise the land and the environment. In such a circumstance, they fear catastrophe may befall their community as punishment from their deceased ancestors.

Twelve Aeta women healers participated in the Talking Circle. To protect the participants' anonymity, pseudonyms were assigned. Most of the women healers claimed that their ways of healing had been passed over by their elders. They were using herbs and spirituality to heal sick people. This signifies that the Indigenous people have been practicing their ways of knowing for a long time. They have seen the efficacy of their healing, thus have passed that knowledge to their kin. This knowledge has the power to be sustained through generations because the community believes that their ways of knowing are more potent. Maya is 70 years of age. She used to get sick when she was young and it is through this experience that she became a healer. At the time of the study she had been a healer for 49 years. She uses herbal plants and rituals in healing. Maya recalls:

When I was young, I wondered why my body was always sensitive and because of this I always felt sick. My parents used to bring me to an Aeta healer. The healer was always nice to me. Every time she performed healing rituals, I made sure that I paid attention. When she was preparing medicine for me, I would always ask questions. I remember one time she asked me why I needed to know everything. I told her that I did not want her to get tired of me, so when I got sick again, I would be the one to heal myself. The healer laughed at me. But at that time, I was already claiming my position in this society as a healer. Since then, I have become a healer. When I do not feel good I treat myself. This practice continued and people started coming to me and asking me to heal them.

This means that healing has gone on even after the influence of the pharmaceutical companies on most Filipino communities. In fact, most Filipino people have had to seek the help of the women healers after they could not find healing in Western medical clinics. Through this, we learn that the Indigenous ways of healing and knowing have always found their place within the Indigenous people themselves.

The Aeta, including their women healers, have maintained fidelity to their beliefs and territory despite much trepidation. For instance, when Mt. Pinatubo erupted, instead of choosing to live in the community of the Christian Filipinos and disregard their own traditions, they chose to stay in 
their village and be with their people. Hardship was a fact of life. During this time, there was no food and no shelter, and their land was infertile. Nevertheless, they did not forget what their ancestors had taught them: when there is a crisis, they must work collectively and pool their faith and efforts. They performed the necessary rituals until a time when they were able to find a solution to their ominous situation. When members in their society fell sick during this bleak epoch, the Aeta women healers did not hesitate to heal. Evidently, these women play an immense role in resisting neo-colonisation as well as in considering and reflecting upon this history in detail in narratives referencing other challenges encountered when maintaining their ways of knowing.

\section{METHODOLOGY AND POWER OF TALKING CIRCLE}

I (author Rose Ann) situated myself in the Aeta community as a doctoral student who was ready to learn and to be taught. Smith (1999) asks an important question that needs to be considered before embarking on research in any Indigenous community: To whom is the researcher accountable? I am accountable to the Aeta Indigenous women healers. I was transparent about the goal of this study and how I would use their stories. I was respectful to their ways of knowing and knowledge production processes (Torres 2012). That is why when the Aeta Indigenous women asked me not to take down notes during the session, or to record the conversation, I followed their instructions. They told me to listen attentively and to join in on the conversation.

The 12 Aeta members decided to talk in a circle instead of individual interview. They divided themselves into three groups, each forming a Talking Circle. The classification and taxonomy were indigenous; they themselves identified who belonged to the different groups. There were, thus, four healers in each Talking Circle. During the study, after the first speaker, anyone who was ready was allowed to respond. After the first round of responses, I asked the second question, and the same procedure followed until the responses to all the questions posed were given. Each Circle lasted approximately two hours. They told me that if I had any questions, I could ask them. After each Talking Circle, I went home and wrote all what I had heard from them. I also wrote my own reflections and observations on the things that they had said. In addition, after holding the three Talking Circles, I visited the women once a week for six weeks. In these visits, I went to their own houses to have informal conversations and to read to them the notes that I had written about the Talking Circles. This 
was to validate the information that I heard from them during the Talking Circle session.

Talking Circles have both a spiritual and cultural relevance to Indigenous people (Prorock-Ernest 2009; Restoule 2004). The spiritual relevance of the Talking Circle has been explained by Prorock-Ernest (2009) who states that it is "rooted in traditional storytelling and religious ceremonies, ...it offers a place where stories of life experiences are shared in a respectful, egalitarian, and non-confrontational manner, in a context of "complete acceptance" by participants (22). Talking in a circle is part of the Indigenous worldview. It is a place where power is exercised with the aim of producing a way of knowing. It is a place where everybody is accepted and not judged. Through the Talking Circle, everyone has power and knowledge that can help in seeking solutions. According to the Aeta women healers, the Talking Circle is a space where there is no animosity, but instead, there is open communication among the group members.

Further, Kovach (1995) states that "it is meant to provide space, time, and an environment for participants to share their story in a manner that they can direct" (124). This is very important because to exercise power, one has to seek it from within and use it to exercise control of one's own environment. This is meant to allow free movement of knowledge from one person to others in a respectful and loving way. It is, furthermore, a space where they can share their healing practices and an emotive and emotional space for laughing and crying. In other words, it is a space where everybody is free to express their opinions and share their ideas. It is also a circle of healing power where everyone is a healer and seeking healing simultaneously (Fitznor 1998; Hart 1996; Prorock-Ernest 2009; Restoule 2004). The Aeta women healers state that, as much as they can heal others, they need healing as well, and they can do this in a Talking Circle. This is where they express the pains they are currently experiencing. As such, the talking circle becomes a space for re-claiming and re-defining power with the sole purpose of decolonising the power dynamics present in a capitalist society.

It symbolises the fundamental truth that we are all inter-connected and that all of us are equally important in this world. Hampton (1995) describes the Talking Circle by stating that "the sharing circles can establish dignity and unity by following the basic teachings of being holistic, in balance, connected, and in harmony. Sharing circles are holistic in that everyone can participate" (69). Everybody within this circle is considered equal. Through this belief system, the Aeta women healers welcomed me in their Talking Circle. 


\section{POWER AS A CAPILLARY}

Anti-colonial discourse interrogates the notion that women are ignorant. Moreover, according to Mills (1998), postcolonial theory is focused on, but not limited to, the following: "assessing the gendered nature of colonialism and its influence on present-day forms of thinking and behaviour, and the worldly focus which forces an interrogation of the nature of 'woman' and 'universal' statements about what women want" (99). Spivak (1995), Mohanty (1995), and Minh-ha (2000) also discuss women-related issues, including women's liberation and emancipation. The discussion traces back to the question of "Can the Subaltern Speak"? Spivak warns us not to romanticise and homogenise the subaltern subject (Shahjahan 2005: 221). Mohanty (1995) explains that this homogenous notion of the oppression of women presents them as ignorant, poor, uneducated, tradition-bound, domestic, family-oriented, and victimised. This representation is very damaging, and the very notion of "oppression" becomes another instance of oppression by stereotyping. This presumption about the oppression of others forecloses our learning the abilities and awareness's of others. We suggest this is the case with our understanding of Aeta healers and their Indigenous knowledge of ethno-medicine. Generalising oppression is, in fact, privileging a certain group and positioning Indigenous women in a very precarious location. The impact of colonisation on women was so profound and negative that they are still considered second-class colonial subjects, unfit to determine their own destinies (Oyewumi 1995). In addition, through Oyewumi's essay, "Colonizing Bodies and Minds," we see how poorly colonisers regarded women. Oyewumi also explains that the analysis of the colonial situation, "in addition to employing race as the basis of distinctions, should take into account its stronger gender component" (257).

In other words, we have to appreciate the role that the Aeta women healers play in the community and thus understand the issues that confront them, such as the fact that their voices are not heard, their knowledge is excluded, and there is a great impact of colonisation on their lives (Dei 2002; Oyewumi 1995; Pecson-Fernandez 1989; Smith 1999; Tauli-Corpuz 2006; Wane 2002). The Aeta women healers need to be acknowledged because history tells us that in pre-Spanish time, they were being recognised as spiritual leaders (Salazar 1989).

The Aeta women healers are completely different from the way they have been depicted in the text. Himay states:

I love serving my family and my community. To me, when I do things for my family and my community, I feel good 
because I know that those little things that I do can help them. For example, when I cook, I am not only cooking for my children and my husband but I always make sure that I include the rest of my people.

For Himay, serving her family and community is not only a responsibility but also a means to help change their situation. For her, a woman who can serve both her family and community possesses the strength, intelligence, and, most of all, the power. Himay considers herself fortunate because she has the power to make sure that the family and community are healthy. She believes that if the family is healthy, then each of the members is able to carry out their respective responsibilities. This can markedly improve their lives. However, if the family or the community is not healthy because their well-being is not attended to, each of them will deteriorate, initiating the demise of their race. Himay feels quite empowered by what she does. She is aware that other people criticise her and label her as an oppressed woman. However, she sees it from a different perspective. In her view, no one can stop her. We can see that Himay is countering the label of Third World women as oppressed, the production of the "Third World Woman" as a singular monolithic subject in some recent (Western) feminist text... (Mohanty 1995).

Essentialising Third World women is a mistake because women in the Third World are very diverse. There should be some recognition of the differences that exist within the larger community of women in the Third World and more especially among the Aeta Indigenous people. Mohanty (1995) states that "the assumption of women as an already constituted, coherent group with identical interests and desires, regardless of class, ethnic or racial location or contradictions, implies a notion of gender or sexual difference or even patriarchy (as male dominance-men as a correspondingly coherent group) which can be applied universally and cross-culturally "(Mohanty 1995: 243). Mohanty argues that applying a generalisation to the condition of women is like recreating the mistake of the fundamentalist; that is, instead of learning from Himay, we are actually pushing her to a location where she cannot find herself. This is what totalising narratives have been doing to Third World Aeta women healers. But this way of thinking is facing reprisal from the practices and narratives of the Aeta women healers. Himay is teaching the society how to pay attention to her. Through this we must become cautious of how we perceive her as an Indigenous woman. Minh-ha (2000) explains why it is important for Himay to say what she needs to say: "you who understand the dehumanization of forced removal-relocation-re-education-redefinition, the 
humiliation of having to falsify your own reality, your voice you know" (246). Himay's narrative is a potent weapon that she can use to re-represent the false notions of who she is.

Furthermore, Rima notes:

As a healer it is not just healing the whole well-being of a person but it is also making our body healthy so that we can make our community rich and healthy. I exist because of my people. Therefore, if one of us is not doing well, we are all affected. To prevent this, I have to do my part, and that is to undertake my responsibility as a mother, a daughter, a wife, an aunt and, most of all, a member of a community that has been there before I was born.

We can see that Rima is instrumental in the health system of her community. She believes in the notion that we are all connected, and therefore, it is important to take care of one another. The power of a community is very fundamental in the deconstruction of what is construed as power. Power cannot find its efficacy if the community is decimated. Indigenous people have practiced their reciprocity from time immemorial. This is because they believe that the weakness of one part can have a great effect to the whole. There is a belief among the Indigenous peoples' ways of knowing that "I am who I am because we are. I need others for my own survival." This notion has been lacking within the capitalist society that believes in individualism and private property. Power is currently taken as property; thus one either has power or is lacking it. With the narratives from Rima, we learn that power is potent among the masses. When you decimate people by situating power on an individual and institutions, power becomes a weapon of destruction. Community therefore is a capillary through which power is effected and exercised.

Rima states her point of view when it comes to do both the work on the farm and in the house:

You know, life is not about counting how many things you have done for your people. It is about doing things that can make a difference in the life of the people that you love and in the life of other people who may be asking for something to eat. You see, what is happening now in our society is that when we do something, we want others to do the same thing and, if not, we place ourselves in a lower position. For example, when I go 
to the farm, I cannot expect my husband to do the same thing. However, there are times when he does not want to go to the farm because, to him, there are other things to do that are more important than farming. When other people see that I am the only one doing the farming, they equate this to being an abused, oppressed, and marginalised woman. However, I look at it from a totally different perspective and that is, I am a strong woman who possesses the intelligence to make my family live and therefore be healthy.

Rima is reminding us not to fall into the trap of believing that Aeta women like her lack both knowledge and reason. When Aeta women are highlighted as objects of analysis, this analysis is manipulated so as to generate negative connotations about them. In other words, this is how the power of language plays its role in defining the other regardless of facts. For example, in the texts the Aeta have been identified as "uneducated" and this term becomes normal and "fine" to define, even if it connotes negativity. In this respect, we can see that language (power of knowledge) can be used to oppress the Aeta and their caregivers. This is why Loomba (1993) cautions that we "engage with current debates about the colonial subject and resistance is also to examine our own construction and to reflect on the possibilities of our articulation. Such a personal stake in subaltern agency may be read as detrimental to 'true' analysis or, on the other hand, as making possible the connection between 'neo' and 'colonialism'" (306).

Before describing the Aeta women healers as "uneducated," let us be careful that we do not downgrade them instead of celebrating their agency. From an outside perspective, it is easy to say that the Aeta woman healer is being exploited because she is performing multiple tasks. However, when we listen to Rima discussing that working is actually for the benefit of her family, we learn that this is a form of strength and power because it produces a healthy community. Lorde (1981) reminds us that "it is our task to educate white women, in the face of tremendous resistance, as to our existence, our differences, and our relative roles in our joint survival" (Lorde 1981: 100). Rima is doing this for us by educating us about their reality.

On issues of gender, Maya states:

In our community as Aeta, there is no such thing as inferior or superior. We treat everybody with equal respect. For example, when we face a situation that requires a decision, we usually 
consult each other; husbands consult their wives and vice versa. We also include our children in the decision-making process. There is no such thing as gender inequality.

Maya explains that gender differences do not exist in the Aeta community. Women are respected. In fact, the Aeta women are "active and capable hunters of wild pig and deer" (Estioko-Griffin 1985: 18). History tells us that hunting is the work of men. However, within the Aeta community, gender division of labour is not part of their belief system (Estioko-Griffin and Griffin 1985). This guides us to the truth that the Aeta community believes in interconnection with one another. No one has power over another. For a community to exist, healthy reciprocity is essential. They try not to compete, although some of the Aeta People are trying to engage in land-owning through formal property titles because of the rise of capitalism. Aeta women healers acknowledge that they are facing such assimilation dilemmas and paradoxes. However, they have to continue reminding their people that their cultural confidence and construction of relations are not about "owning" property but rather about taking care of the land and sharing land and wealth with community members.

Amay also explains her role as a woman in her family and in the community, which shows that gender inequality does not exist. She also shares the notion of "the light of the home and the community":

As a woman, when there is conflict I stand in the middle to ask the people what their concern is and whether it is necessary to resolve it by beating each other or through a peaceful and respectful manner. In my house, there are times when other members of the family become angry. Instead of getting angry, I talk in a way that the other person feels loved and respected. In my community, when I heal, I let the person know that I am there for her or him. I reassure my people that I work for my community, not for myself alone.

Amay learned from her ancestors to always advocate for peace and love in both her family circle and in the community. Respect, love, and equality are most important to the Aeta women healers. For them, the issue of gender inequality is not part of their culture. This kind of discourse actually does not concern them. What is important to them is that everybody has an equal share of every opportunity that their Creator provides for them. 


\section{NEXUS OF KNOWLEDGE}

The Aeta represented by their women healers look at life from a perspective that is more integrated and communal and less atomised and individualised than the Western model. Aly, for example, stresses that she does not focus on material things or on how much she can make in healing. She focuses instead on helping other people. She talks about believing in what she does and how it will help her community. She states:

There may be a health centre in our community, but there are still so many people who come to me because they believe in my healing power. I have been healing very many people who have been bitten by snakes, among other things. Some of them were about to die when they came to me. But, through my knowledge of healing, and with the help of my Creator, I was able to help them. There are times when I feel so weak, but I still perform healing because if I refuse to heal the people who are in need of help, I feel worse. My work as a healer is the one that gives me strength and happiness. I believe that I possess the knowledge that can help the people who are in need. It is a power not only to change the life of my people but also the life of other people. I do not ask for money or any material things. I only ask the people who come to me to believe what I do and to respect my people.

For Aly, the well-being of her people and others is the raison d'etre for her vocation. Healing may sometimes be harsh, for example, when she is exhausted, but she continues working despite her own exhaustion in order to improve the health of others in the community. Improving the people's health conditions for the better is one of the reasons she continues to heal. Aly states if the existence of a health centre affects their healing practices:

I'm glad that the health centre exists in our community because there are things that I cannot do. For example, I cannot tell the exact temperature of a person who is having a fever. I believe you need some instruments to do that. In the health centre, they have it. However, there are things that the health centre does not have that I have. For example, when a person is bitten by a snake, I can tell right away. I do not need any instrument to do it. 
Aly recognises the importance of a health centre in their community. Her attitude does not exhibit any hostility, and she does not see other health services in the community as rivals or competition. Indeed, she acknowledges that the health centre has things she does not have. For her, what is important is that she is healing people who are sick because she wants to improve their health. Aly does not ask her patients for money. She states that healing people - not making money-is the main goal. She believes that if she does her calling, God will provide for her needs. It is up to those who have been healed to give her what they can afford in terms of a gift, such as vegetables, sugar or rice. However, this is not considered payment for the service rendered. This is precisely the type of argument anthropologist Marcel Mauss posed in his classic work The Gift (Mauss 1967). Mauss argued that in pre-capitalist societies (i.e., societies free of capitalists organising the concept of private property, and hence transferability, and the intended ability to alienate one from one's own labour as argued by Marx, Montesquieu, and others), in the act of social relations there was a particular set of relationships whereby one's own relationships of work and production became inalienable and nontransferable. Therefore, a special relationship was organised in the de facto economic relationships of the gift. The relationship is not one of buying a service as one might from a doctor but instead is a relationship of reciprocal stewardship implicit in the organisation of the society and localised relations. This is very close to the kind of argument we understand Aly to be denoting in her statement.

Aly also asserts her knowledge of healing. For her, the healthcare function is to produce the true version of reality: by unifying the spiritual and the material, the Aeta women healers save lives. Aly knows that she may have the knowledge to heal, but she acknowledges that other people or other entities in the society also have their ways of healing. She has admiration for others who have different ways of healing or curing diseases. She states that if public health practitioners were open for dialogue with Aeta women healers, the notion of competition or actions to damage others would be diminished. Aly knows that, with respect to public health, they are not given recognition as agents that provide healing serves among the population. She notes that most of the medicine used by public health staff is from herbal plants. The only difference is that they patent the plant, blend the herbal mixture with other substances, and package it in a decorative container that is appealing to consumers.

Aly knows that the goal is not to eliminate the disease but rather to make a profit. She says I may call her "bagtit," Ilokano for crazy, but the fact is that healing in the public health system is not completely for the 
benefit of the people but is also for the proliferation of vested interests. Even then, she is not totally dismissing the work of public health because it has been helpful to the infirm who can afford to buy medicine. She states that it is time to voice her reflections on the impacts of the modern world. Along the same lines as Aly's thinking, Larkin (2006) writes:

The health problems and prospects within the poorer regions of the Third World are intricately caught up in these development processes. It is within and through the complex web of influences at play that health and health issues come to be defined, shaped, and experienced. However, these processes can no longer be understood solely within the confines of particular countries or nation-states. As Western technologies, cultures, and ideologies spread around the globe and insert themselves into the Third World, so increasingly development and health issues become caught up in and are shaped by these globalizing influences.

The above argument by Larkin agrees with Aly's explanation that medicine can only be afforded by the affluent. It is a clear depiction of the fact that contemporary medicine, as implemented in the Philippines, is an organisational delivery structure whereby many suffer while few prosper. Profit, rather than healing, is the objective of the central mandate of this endeavour. Medicine by commoditisation has been used as a contrivance to divide and rule. According to Aly, it is the haves in society who tend to go to the health centres. The rest of the population is doomed to languish, die, or seek the help of Indigenous healers; this has a great demographic and hygienic impact on the poor population of the country as the country's poor exceed the number of people who can afford services at public health clinics and who can afford to buy the medicine (Encyclopedia of Nations 2011).

This phenomenon is a classic instance of how the introduction of the Western medical system has been complicit in creating classes of people within a society. In the Philippines, even with an established medical system, there is a further divide. The system is a hybrid of the public and private where the poor are always relegated to the former if they receive any care at all. In much of the Third World, the Western medical model's application has become a catalyst for the oppression of the most vulnerable in societies. By contrast, instead of dividing the population along this wealth partition, the Indigenous sector of the healing community, in which our participants are models, has been acting as both a uniting factor and a source of solace to the disposed. Larkin is arguing that the root cause of this 
problem, which affects the Filipino people, originated from Western technologies, cultures, ideologies and proprietary practices. The Aeta healers, without reading Marx, Foucault, or Fanon, have interrogated and analytically crystallised their own institutional ethnography (Smith 2005). They have concluded that the medical models of the establishment offered gave rise to a process whereby an entrenched system makes the most vulnerable poor and defenceless against the internalisation of the false consciousness of their status. Meanwhile, practitioners inside the system are not sufficiently critical in their understanding of what is needed for an effective medical delivery system-one that processes the demographic, health, socio-economic, and cultural realities of the country and comes up with adaptive planning and implementation of health care delivery using all appropriate resources available that are both functional and appropriate. Instead, they have too frequently indulged in sophistic arguments ranging from "blaming the victim" models (Ryan 1976) offered in the "modernist" arguments to acting as if these should be the overarching factors in justifying such an unequal health care delivery system.

The Aeta healers have their own medicine that they use for themselves and for others who believe in their healing practices. Their medicines are available for everybody and therefore constitute a genuinely "universal" health care system. No one is excluded because of race, class, gender, and ethnicity or any other difference. Indigenous healing is for the benefit of everybody, without subjecting them to the torment and artificially induced self-loathing cause when someone is made to feel like a second class citizen in a land that was, after all, his or her homeland.

\section{AETA WOMEN'S INDIGENOUS POWER TO RECOGNISE THE EXISTENCE OF THE COSMOS}

As part of her healing practices, Rang-ay asks everybody to take care of their environment. She states:

As a woman healer who has the power to speak, I would like us to take care of our Mother Earth. All the things that I need in my healing, I get them from the land. But at the same time I do not leave the plant to die. When I need leaves from a plant I only take the leaves, not the whole plant, because I know that if I uproot the plant then others cannot use it anymore. Today, I am very worried because non-Aeta people come to the forest and cut the trees. That is why you do not see so many trees 
anymore. It pains me when they do this because I know the impact on us. I talked to these loggers one time and begged them not to cut the trees.

Instead, they insulted me and told me that I was just an Aeta woman who did not have any importance in the society... I believe that the land, the trees, and all the creation in this world must be respected and taken care of.

Rang-ay is calling for environmental conservation. She is aware of the environment-related challenges they are facing, such as, "the worsening of the quality of their lives in terms of insecurity, poorer health, less food, the worsening quality of air, water and soil, decreasing income opportunities, degraded social conditions, and little if any political power... All the promises of progress have passed them by and left them saddled with many of the problems" (Lamba 2005: 2). When the Philippines became a part of the "global capitalist system and how it has come to dominate the world" (Lamba 2005: 2), communities of the Aeta people, where Rang-ay lives, were tremendously affected. Rang-ay is experiencing the environmental changes: for example, the weather has become extremely hot and humid. Furthermore, most of the herbal plants she has been using in her healing are gone because of patenting.

We would like to speculate that the extension of intellectual property, including the patenting of medicine and use of the sequencing of the genome and the genetic code, represents one of the most insidious and unwarranted extensions of power appropriation and concentration. This extension represents a substantive threat to global health in the past quarter century. Consider this menace in terms of epistemology. The largely plantbased remedies that the Aeta use from the "pharmacy" of their forest and agriculture lands have palliative veracity because of their healing properties regardless of which ones the likely etiological model uses. Irrespective of the causal attribution for the cure, there remains one underlying claim. The primary concept is that the determinant root cause of the healing, be it from the spirit, our DNA, or our chemistry, is the external force that made us and continuously remakes us. What is common throughout these models is that we did not "make" the world. The sequencing and "proprietary authorship" is clear in each of these analytical models. By patenting the elements of nature that we use, we, as scientists or corporations, are in effect claiming to be God. This can have preposterous outcomes: for example, chemical and pharmaceutical companies have patented as intellectual property parts of the Genome Code (which was publicly funded in the US and the UK) as well as 
the parallel private project whose members have frequently borrowed from the public project "for free" (as in, used knowledge produced with public monies as their own). This "borrowed" information was repackaged for proprietary patents, or as "their own." Chemical companies using these legal creations (created largely by unequal lobbying) have, for instance, sued farmers in Canada whose crops were cross-pollinated with Monsanto genetically-engineered products that had become airborne (Fox 2001). In some markets, the seeds available will only germinate once, and even this single crop model (plants thusly grown will not produce seeds themselves) requires pesticides - sold by the company also selling the seeds and therefore collecting twice the sales - to germinate. Did multi-nationals create nature or are they themselves God? These projects use proprietary practices not unlike land expropriation to privatise Indigenous knowledge that has been understood for ages and then act as if they were the creators.

The use of antibiotics, while in the short run helping those who can afford them, has yielded drug resistant or "super strains" of diseases (WHO 2012). Recall the conclusions from Crosby's work in the Columbian Exchange (1972): disease and ecological disruption, even more than war, have been the sources of mass destruction that have devastated people historically. This was certainly true for Indigenous peoples. In North America, the death toll was at least more than five million, and in South America and the rest of the world, genocidal levels are much higher. The smallpox outbreak in the Northwest Coast of Canada, for instance, may have killed upwards of one third of the population (History Link 2003). It was, after all, the black plague brought along the silk road opened by the Moguls (Weatherford 2004), which temporally ended trade and disposed of more than a third (or 1.5 of an estimated 4 million) of the inhabitants of Europe (see, for instance, The History Learning Site 2015).

It is precisely these kinds of central epidemiological and social consequences that our participants are pointing to within their "databases." They are also implicitly inviting us to honestly interrogate the consequences of our own arrogance, oversights, and the dysfunctional elements of our own value and health delivery systems. In this respect, it is clear that the Aeta women healers are critical "organic" intellectuals. One can speculate how "enlightened" or "rational" a system such as the official health delivery system in the Philippines wishing to embrace a value schematic that superimposes proprietary rights over our natural human obligations and, as UNESCO states, the "right" of a child to both health care and education. How effective is a system that establishes uneven distribution and leaves pockets of poverty in which once "extinct" diseases are allowed to rise again? Who are the "barbarian" and the irrational in this problem and what 
are the inherent effects such a health care model generates? These are questions beyond the scope of this study that should be later pursued. It is sufficient to note here that as we reflect, we may wish to consider what the stories and analyses of the Aeta women in my study show us: parallels in anticipation of many of the most vanguard epidemiological issues debated in modern health. We see these global issues reported on by our Circle member's in local and specific contexts.

For Rang-ay, it is worth noting that it is hard for her to catch fish in the river because some of the non-Aeta fishermen use bombs to catch fish, such that even the smallest fish die. The Aeta people have their different ways of catching fish, mainly using nets, which catch only big fish so that the small fish continue to grow. Gathering wild fruits is now a struggle because of the issues of deforestation and mining. This further extends to include the issue of hunting wild animals. Most of the wild animals are gone, which has led to concerns relating to food scarcity. The challenges that the Aeta women healers are facing are also being faced by the Cree people in Canada. Feit (2004) writes the following about the governmentasserted dominance over the Cree people in Canada:

The expansion of the rail and road networks into the southern portions of Cree territory occurred in the 1950s and 1960s, and several mines, mining towns, and commercial logging operations were established. Their impacts on the Cree were neither foreseen nor considered... Cree reported frequent findings of dead fish and aquatic animals and changes in the taste of animals over large areas (112).

However, the Cree people did not capitulate and allow the government to rule over them: "dozens of Cree hunters came to Montreal to testify, explaining to judge Albert Malouf, government representatives, and the public how they lived on the land and why they had to have a say in what was done there. Their tone was not confrontational but truthful and firm" (Feit 2004: 114). The Aeta women have been doing the same thing with respect to the integrity of their land. They take a stand on matters relating to their community. One example is Rang-ay's statement advocating for environmental conservation. We can see that what matters to the Aeta women healers is also significant to the Cree people of Canada. They may be living in two different worlds, but they share a common concern. Indigenous knowledge, as exemplified by the Aeta women healers, is based on love for Mother Earth. They are community nexus connectors between the material and the spiritual worlds. They accept that if they take anything 
for granted, the repercussions will return cyclically over time. They live with the understanding that they exist for their community rather than for themselves.

\section{DISCOURSE}

Outsiders have disposed of the Aeta healers for a long time. The military forced them to leave their ancestral land because it had been appropriated by a wealthy person. They therefore could not reside on that land. Because of this, they were forced to live in locations close to the cities, where they were being governed by city politicians with little knowledge of or interest in their plight. They were mandated to follow the rules and regulations to the point where they were functionally dictated to abandon their culture. My conversation with our Aeta healers has shifted my thinking regarding survival from these forms of challenges. Rosa states, "I heal because I resist assimilation into the modern way of life." This statement informs us that Aeta women healers are not ready to give up their traditions and practices in exchange for modern life. For Rosa, healing is a way of resisting neocolonisation. Not only does she resist neo-colonisation, she also heals the injured spirits of her people. These injured spirits have been caused by their shift to other lands, departure from their ancestral land, and loss of their cultures. They not only leave the land physically, they also leave the places where their ancestors are buried. It is in this context that the imperative for healing is greatest, and Rosa fulfils this psychic necessity. She heals her people's physical as well as emotional and spiritual ailments. She knows that when they are well in all aspects, they can resist the treatment forced on them by outsiders.

Global capitalism has mastered the paraphernalia used to hoodwink the locals. Nonetheless, the Aeta women healers see through these apparatus. Rosa's testimony details why she does not want to succumb to the operation of global capitalism. She knows the consequences for her people. She also knows that one way of dismantling global capitalism is saying no to the modern way of living. This is because she knows that the moment she agrees to the manipulation of the global system, she will be making a culturally and ecologically grievous mistake. Rosa, therefore, is standing firm and holding onto her way of life: one that is connected to nature and to honouring other creations. For her, life is not just about having many material possessions, it is rather about sharing whatever you have with others. It is not just about taking ownership of everything that exists in the universe; it is also about respecting and taking care of others. Finally, life is not just living as an individual; it is about living with others. Rosa expresses 
her disappointment with modern society:

I feel sad to see how this modern way of life is treating the creations of our God. Nowadays you can see a lot of killings because of greed, jealousy, and hatred. Everybody wants to be at the top of the ladder. To do so, they have to hurt their own fellowmen. Another thing is when my children go to the market, others treat them like animals, for example, hitting them with a stone. This is a painful experience. I do not want my children to learn any of these kinds of values. In our own community, we tried to respect each other. We talked about helping each other and sharing whatever we have. These are some of the reasons why I do not want to be connected or assimilated in this way of life. There was also one time when I went to the health centre, hoping that they [could] help my child. I respect their ways of healing, so I asked for advice on what I could do to [heal] my child who had a fever at that time. Instead of this nurse advising me, she gave me a box of medicine. The nurse did not explain to me how I was supposed to use it. For this nurse, I do not have a brain, so there was no point explaining. I looked at the box of the medicine and checked the expiration date, and I found that the medicine expiry date had already passed. It hurts so much to see how the nurse treated us. Nevertheless, I went home full of hope that I could heal my own child. I prayed to my God, and I applied and boiled some herbal plant and gave to my child. I did this a few times. Fortunately, my child got healed... I prefer to continue living the way we do.

We can see that although Rosa has tried to use modern medicine, she decided to protect her family and her culture because of the way the nurse treated her and her child. She believes that her healing may be imperfect but, to her, there is a multitude of reasons why she should continue to practice it. In her heart, she is acutely aware that she is making a change not only in her life but also in her community.

Rula is also steadfast in using herbal plants instead of yielding to the power of Western medicine. Rula states, "We have to make sure that, even though we have access to modern medicine, we keep using herbal plants because there are things they can help to heal our body." I asked Rula about her experience with modern medicine. This is what she said: 
Well, I have had both positive and negative experiences. I went to the health centre because I had a terrible headache. I wanted to get healed quickly because I had things to do. I asked for medicine and they gave me. I took it, and a few minutes later the headache was gone. I was very happy about it. However, after a few days, the headache came back. I went back to the health centre. This time the staff at the health centre gave me a bottle of medicine. The staff did not inform me how to take it but because I told her that the headache had come back, I assumed that the medicine was for headache. However, when I took the medicine, instead of getting better, I ended up getting diarrhoea. I wondered what possibly could have gone wrong. So this time I went to the health centre to complain. One of the staff looked at the medicine that I had been given. I could see that she was shocked because the medicine was not for headache but for other illnesses. I waited for a few hours to see what these staff could do about my complaint and my illness. What they did was, they asked me to come some other time. They did not apologise for what had happened. I went back to my house full of anger. Later I realised that it could be a sign that I should stop going to the health centre. Since I am a healer, I prepared some medicinal plants for headache and for diarrhoea and I got well. These herbal plants are hard to find, and it is a complex process before one can actually use the product. In the end, it is beneficial to our body. So, as an Aeta healer, I prefer our own ways of healing to taking this modern medicine because of the side effects. For herbal plants, you do not need to worry about side effects as long as you know the right plant for the disease.

From Rosa's and Rula's testimonies, it is clear why they resist modern models of life and healing. First, it is personal experience and negative experience. Second, they want to demonstrate that their healing practice is beneficial to all, and they do not want to be manipulated and act as pawns in a game directed by global marking and corporate health agendas. Through the work of Rosa and Rula, the goal of global capitalism has been disrupted, and the new way of medicine has had a hard time surviving in the lives of the Aeta people. 


\section{CONCLUSION}

In conclusion, this article identifies diverse and multiple ways through which Aeta Indigenous women healers exercise power. In contemporary society, the belief is that power is domiciled at the top of any political state structure. This totalising power discussion sees power as coming from the top. Anything from the edges is considered as powerless. This Hobbesian way of power analysis has been complicated by the Aeta Indigenous women healer from Cagayan Valley in the Philippines. To them, power can also come from the margin. This kind of power is communal and meant to benefit all within and without the community. Healing is such a power. They heal people as a way of exercising their power and as such benefiting the community. Foucault states that power should not be seen like a commodity. Power cannot be possessed. It is a fluid concept. This means that power flows through a capillary in such a way that those who may seem marginalised, they are able to exercise their agency and resistances through their practices and knowledge production. This was manifested by Aeta Indigenous women through deciding the kind of methodology that they wanted to be used. This kind of resistance disturbs colonial research practices present in most academic spaces. It troubles totalising Eurocentric narratives of research process. Discussions of this level, allows us to seek gaps and not wrongs in any discourse. The work of Aeta Indigenous women healers is to identify that which is oppressive with an intent of bringing social justice in knowledge production and practices. Power politics is not all about dislodging the leviathan but rather identifying structural imbalances that condone injustices. The fact that Aeta Indigenous women healer decided to be interviewed in a circle expresses more about power invested within a community. It is power build out of responsibility, respect and relationship building. When producing knowledge, a sense of respect and responsibility is paramount. This was key element within the Aeta Indigenous women healers during the interview. The knowledge produced within the community is meant to benefit all. Researchers in the past have identified margins as a space of powerlessness and in need of a saviour. This kind of theorisation denies the agency and power that those in the borders wield. It makes marginalised people question themselves. This internalisation of powerlessness renders them more of victims rather than victors.

Today, the work of Indigenous peoples is too often characterised in informal settings as devoid of sense and, thus, marginalised. Furthermore, its expertise is under-represented and presented as tacit informal practices within the academic circle. We may be promoters of equal justice and 
fairness in society, but if we do not recognise our roots and cultures in our teachings, anything we proclaim about justice will be an incomplete epistemic. We need open exchanges since they are the heart and soul of what is generally understood as "ethics," open discourse, and "bias free" inquiry. Our academy is still involved in the colonial beliefs that tend to deny that the Indigenous peoples' knowledge belongs in a safe space. In fact, we have ended up imposing a death sentence on would-be scholars by claiming that choosing this area limits job prospects. This is a Eurocentric mentality in its most plain, apparent form, and the prejudice has manifested a bias that has been taken to levels bordering on disgrace.

There are, and should be, levels of engagement and varying degrees of "proof" in a valid epistemological assessment. One potential methodological critique of our own claims made here, for instance, is frequently and often correctly made towards anthropologists: the claims are single accounts (and therefore single cases) with no independent check on spurious or exogenous factors nor cross-checks on inherent bias particular to the observer. They are therefore lacking validity and consequently are suspect in terms of fundamental methodological criteria of both reliability and validity (Campbell and Stanley 1966). Put another way, one might ask sociologically (and logically) where is the counter interrogation of the negative space that is created by stigmatising individuals using judgment that is offered frequently without the possibility of counter analysis or even an open discussion of merit? Consequently, this article identifies the strengths of Aeta Indigenous women healers by bringing to fore diverse ways through which they exercise power as a community.

\section{NOTES}

* Rose Ann Torres has a PhD in Sociology of Education and Women and Gender Studies at Ontario Institute for Studies in Education (OISE), University of Toronto, Canada. She has been teaching at Sociology Department at Ryerson University and Trent University, and in the department of Women and Gender Studies at Brock University, Toronto. Her research and teaching interests are in the areas of community engaged research theory and methodology, Indigenous studies, inequities, critical anti-racism, gender variance, politics of resistance, inclusive education, post-colonial theory, anti-colonial theory, feminist theory, transnational studies, and sociology of knowledge. She is currently conducting a community engaged research on "The Diasporic Resiliency, Agency and Resistance of Filipino Women: Roles, Influences, and Experiences."

** Dionisio Nyaga is a $\mathrm{PhD}$ candidate and college instructor in Ryerson University, Social Justice Education, Ontario Institute for Studies in Education (OISE), University of Toronto, Canada. His research fields include men and masculinities, 
critical masculinity, indigenous studies, anti-colonialism, post-colonialism, antiracism, African studies, trans-national and diasporic studies, and anti-oppressive social work and practice.

\section{REFERENCES}

Campbell, D. and Stanley, J. 1966. Experimental and quasi-experimental design in the social sciences. Chicago, IL: Rand McNally.

Crosby, A. 1972. The Columbian Exchange: Biological and cultural consequences of 1492. Westport, CT: Praeger.

Dei, G. 2002. African development: The relevance and implications of "indigenousness." In Indigenous knowledges in global context: Multiple readings of our world, eds. Dei, G., Hall, B. and Rosenberg, D., 70-86. Toronto: University of Toranto Press.

Encyclopedia of Nations. 2011. Philippine poverty and wealth, 2011. http:/www.nationsencyclopedia.com/economies/Asia-and-the-Pacific/ Philippines-Poverty-and-wealth.html (accessed 10 October 2011).

Estioko-Griffin, A. 1985. Women as hunters: The case of an eastern Cagayan Agta group. In The Agta of Northeastern Luzon: Recent studies, eds. Griffin, B. and Estioko-Griffin, A., 19-32. Cebu City, Philippines: University of San Carlos.

Estioko-Griffin, A. and Griffin, A., eds. 1985. The Agta of Northeastern Luzon: Recent studies. Cebu City, Philippines: University of San Carlos.

Feit, H. 2004. Hunting and the quest for power: The James Bay Cree and Whiteman development. In The Canadian experience, eds. Morrison, R. and Wilson, C., 101-128. Don Mills, Ontario: Oxford University Press.

Fitznor, L. 1998. The circle of life: Affirming aboriginal philosophies in everyday living. In Life ethics in world religions, ed. McCane, D., 21-40. Atlanta, GA: Scholar Press.

Foucault, M. 1980. Power/knowledge: Selected interviews and other writings, 1972-1977. New York: Pantheon.

Fox, J. L. 2001. Canadian farmer found guilty of Monsanto Canola patent infringement. Nature Biotechnology 19: 396-397.

Gravan, J. 1964. The Negritos of the Philippines. Vienna: Verlag Ferdinand Berger Horn.

Hampton, E. 1995. Memory comes before knowledge: Research may improve if researchers remember their motives. Canadian Journal of Native Education 21 (Supp. 1): 46-54.

Hart, M. A. 1996. Sharing circles: Utilizing traditional practice and methods for teaching, helping, and supporting. In From our eyes: Learning from indigenous peoples, eds. Meara, S. and West, D., 59-72. Toronto: Garamond Press. 
The History Learning Site. 2015. The Black Death of 1348 to 1350. http://www.historylearningsite.co.uk/medieval-england/the-black-death-of1348-to-1350/ (accessed 6 October 2011).

History Link. 2003. Smallpox epidemic of 1862 among Northwest Coast and Puget Sound Indians. http://www.historylink.org/index.cfm?DisplayPage= output. cfm\&file_id=5171 (accessed 5 October 2011)

Jocano, F. L. 2000. Filipino Indigenous ethnic communities: Patterns, variations, and typologies. Manila: Punlad Research House.

Kovach, M. 2009. Indigenous methodologies: Characteristics, conversations, and contexts. Toronto: University of Toronto Press.

Lamba, H. 2005. Rethinking progress: Towards a creative transformation of global society. Delhi: Daanish Books.

Larkin, M. 2006. Global aspects of health and health policy in Third World countries. In An introduction to women studies: Gender in a transnational world, eds. Grewal, I. and Kaplan, C., 119-129. New York: McGraw-Hill.

Loomba, A. 1993. Overworlding the Third World. In Colonial discourse and post-colonial theory: A reader, eds. Williams, P. and Chrisman, L., 305323. Harlow, UK: Pearson Education.

Lorde, A. 1981. The master's tools will never dismantle the master's house. In This bridge called my back: Writings by radical women of colour, eds. Moraga, C. and Anzaldua, G., 98-101. Latham, NY: Kitchen Table Press.

Minh-ha, T. 2000. Not you/like you: Postcolonial women and interlocking questions of identity and difference. In Post-colonialism: Critical concepts in literary and cultural studies, vol. III, ed. Brydon, D., 1210-1215. New York: Routledge.

Mills, S. 1998. Post-colonial feminist theory. In Contemporary feminist theories, eds. Jackson, S. and Jones, J., 98-112. Edinburgh, UK: Edinburgh University Press.

Mohanty, C. 1995. Under Western eyes feminist scholarship and colonial discourse. In Post-colonial studies reader, eds. Ashcroft, B., Griffiths, G. and Tiffin, H., 242-245. New York: Routledge Taylor and Francis Group.

Mauss, M. 1967. The Gift: The forms and functions of exchange in Archain society. New York: Norton Libraries.

Oyewumi, O. 1995. Colonizing bodies and minds. In The post-colonial studies reader, eds. Ashcroft, B., Griffiths, G. and Tiffin, H., 256-260. New York: Routledge.

Pecson-Fernandez, A. 1989. Why women are invisible in history. In Women's role in Philippine history: Selected essays, 2nd ed., 1-21. Quezon City, Philippines: University Center for Women's Studies, University of the Philippines. 
Prorock-Ernest, A. 2009. A culturally-relevant, emergent approach to exploring the needs, strength, and priorities of tribal communities in Virginia. https://digarchive.library.vcu.edu/bitstream/handle/10156/2506/AmyProroc kErnestThesisLibrary.pdf?sequence=3 (accessed 12 October 2011).

Restoule, J. 2004. Male aboriginal identity formation in urban areas: A focus on process and context. PhD diss., University of Toronto, Canada.

Ryan, W. 1976. Blaming the victim. New York: Vintage Books.

Salazar, Z. 1989. The Babaylan in Philippine history. In Women's role in Philippine history: Selected essays, 2nd ed. Quezon City: University Center for Women's Studies, University of the Philippines.

Shahjahan, R. 2005. Mapping the field of anti-colonial discourse to understand issues of indigenous knowledges: Decolonizing praxis. McGill Journal of Education 40 (2): 213-240.

Shimizu, H. 1989. Pinatubo Aytas: Continuity and change. Quezon City, Philippines: Ateneo de Manila University Press.

Smith, D. 2005. Institutional ethnography: A sociology for people. Toronto: Alta Mira Press.

Smith, L. 1999. Decolonizing methodologies: Research and indigenous peoples. London: Zed Books Ltd.

Spivak, G. C. 1995. Can the subaltern speak? In The post-colonial studies reader, eds. Ashcroft, B., Griffiths, G. and Tiffin, H., 28-37. New York: Routledge.

Tauli-Corpuz, V. 2006. Our rights remain separate and distinct. In Paradigm wars, eds. Tauli-Corpuz, V. and Mander, J., 13-21. San Francisco, CA: Sierra Club Books.

Torres, R. 2012. Aeta indigenous women healers in the Philippines: Lesson and implication. PhD diss., Institute for Studies in Education, University of Toronto, Canada.

Wane, N. 2002. Indigenous knowledge: Lessons from the elders - A Kenyan case study. In Indigenous knowledges in the global contexts: Multiple readings of our world, eds. Dei, G., Hall, B. and Rosenberg, D., 54-69. Toronto: University of Toronto Press.

Weatherford, J. 2004. Genghis Khan and the making of the modern world. New York: Three Rivers Press.

World Health Organization (WHO). 2012. A world free of TB antibiotic resistance. http://www.who.int/mediacentre/factsheets/fs194/en/ (accessed 12 October 2011). 